Marquette University

e-Publications@Marquette

Theology Faculty Research and Publications

Theology, Department of

$1-1-2013$

\title{
Adoil Outside the Cosmos: God Before and After Creation in the Enochic Tradition
}

Andrei Orlov

Marquette University, andrei.orlov@marquette.edu

Published version. "Adoil Outside the Cosmos: God Before and After Creation in the Enochic Tradition," in Histories Of The Hidden God: Concealment And Revelation In Western Gnostic, Esoteric, And Mystical Traditions. Eds. April D. De Conick and Grant Adamson. Durham, ENG: Acumen Publishing, 2013: 30-57. Publisher Link. (C) 2013 Acumen Publishing. 


\title{
CHAPTER 2
}

\section{ADOIL OUTSIDE THE COSMOS \\ GOD BEFORE AND AFTER CREATION IN \\ THE ENOCHIC TRADITION}

\author{
Andrei A. Orlov
}

... vessels shattered and collapsed, for they were not able to contain the light expanding and emanating from within them ... the saints in their death transform these sparks of holiness.

Chaim Vital, Etz Chaim

Unlike other early Enochic writings, the 2 (Slavonic) Apocalypse of Enoch depicts a unique story of primordial creation, revealing an elaborate course of events that preceded the visible creation of the world. ${ }^{1}$ The importance of this mystical account is underlined by the fact that it was delivered to the seventh antediluvian hero by God himself. Chapter 25 of 2 Enoch recounts how, at the end of the patriarch's celestial tour to the Throne of Glory, the deity unveils to the seer that prior to the visible creation he had called out from nothing the luminous aeon Adoil to become the foundation of the upper things. The account describes the enigmatic event of Adoil's disintegration in the course of which the aeon becomes the cornerstone of the visible creation upon which the Deity establishes his Throne. Here, similar to the depictions found in the Lurianic Kabbalah, the bursting of the primordial vessel of light is envisioned as the first creative act of the deity that gives life to the visible order of everything.

Even more striking is that this primordial act of establishing the visible reality is then paralleled in the later chapters of the Slavonic apocalypse that focus on the eschatological demise.

Thus scholars have previously noted that the protological account in chapter 25 , dealing with the establishment of the created order, appears to correspond with the order of eschatological events in chapter 65 where during his short visit to earth Enoch conveys to his children the mystery of the last times. ${ }^{2}$ The patriarch reveals that after the final judgment time will collapse and all the righteous of the world will be incorporated into one single 
luminous entity: the aeon of the righteous. The description of this final aeon betrays some striking similarities to the primordial aeon Adoil depicted in chapter 25. The revelation also seems to suggest that the righteous Enoch, translated to heaven and transformed into a luminous celestial creature, represents the first fruit of this eschatological aeon that will eventually gather all the righteous into a single entity.

The purpose of this chapter is to explore the traditions about the primordial aeon Adoil in the Slavonic apocalypse and the role of Enoch in its eschatological restoration.

\section{THE AEON BEFORE CREATION}

\section{The Upper Foundation}

The Slavonic apocalypse underlines the portentous nature of the primordial cosmogonic account by stressing that this special knowledge has never been previously revealed to any other creatures, including the angels. This supraangelic disclosure, given to the visionary after his celestial metamorphosis, can be seen as the pinnacle of the esoteric instruction the seventh antediluvian hero acquired in the upper realm. An extensive description of this revelation is provided by both the shorter and the longer recensions of the Slavonic text. The shorter recension ${ }^{3}$ of 2 Enoch 25 offers the following account:

And I commanded the lowest things: "Let one of the invisible things come out visibly!" And Adail descended, extremely large. And I looked at him, and, behold, in his belly he had a great age. And I said to him, "Disintegrate yourself, Adail, and let what is disintegrated from you become visible." And he disintegrated himself, and there came out from him the great age. And thus it carried all the creation which I had wished to create. And I saw how good it was. And I placed for myself a throne, and I sat down on it. To the light I spoke: "You go up higher and be solidified and become the foundation for the highest things." And there is nothing higher than the light, except nothing itself. And I spoke, I straightened myself upward from my throne. ${ }^{4}$

The central character of the story is the aeon Adoil ("Adail" in the shorter recension) $)^{5}$ who is envisioned in the text as the chief cosmogonic agent responsible for the "revelation" of the visible creation. This enigmatic entity is depicted as both the mother and the midwife of creation, someone that conceives and then releases the whole creation from its cosmic belly. The text emphasizes the enormous size of Adoil, defining him as "extremely large." $\mathrm{He}$ is portrayed as "pregnant" with creation by containing a great aeon in 
his stomach. According to the text, Adoil's disintegration provides the beginning for all visible reality and serves as the foundation on which God is able to establish the first visible manifestation of the created order: his Throne. It is noteworthy that in both recensions the Deity commands Adoil to become the foundation of the highest things. ${ }^{6}$ This terminological identification of Adoil with the concept of foundation is important for our study. ${ }^{7}$

Another significant feature relevant to our subsequent discussion is the portrayal of Adoil in the longer recension as the "revealer." Adoil's disintegration is identified in the text as the revelation of the created order: "And the great age came out, and it revealed all the creation which I had thought up to create."

Finally, another notable detail in the depiction of Adoil is the repeated references to his luminous nature. The emphasis on the luminosity of the primordial aeon is even more apparent in the longer recension, which emphasizes not only the outer shining nature of the protological agent but also his internal luminous state, depicted there as a pregnancy with great light. ${ }^{9}$

\section{The cosmogony of 2 Enoch: Light inside of light}

Scholars have previously noted several parallels between the creational narrative found in the Slavonic apocalypse and some Hermetic and Gnostic cosmogonies. Futher, the researchers often envisioned 2 Enoch's account as an important early testimony to the Jewish matrix of these later cosmogonic speculations..$^{10}$ In light of these similarities, scholars speculated that Adoil's imagery may be connected with the myth of the Celestial Man. This imagery becomes prominent in the later Hermetic and Gnostic texts and collections, ${ }^{11}$ including the Corpus Hermeticum where the Anthropos inherits the luminosity of the Father ${ }^{12}$ and becomes the blueprint for the created order and humankind by disintegrating himself into the physical realm. This motif is conveyed in the Poimandres ${ }^{13}$ through the erotic metaphor of Anthropos falling in love with Nature ${ }^{14}$ In commenting on the features of the Celestial Man myth in the story of Adoil, Jarl Fossum draws attention to the peculiar symbolism of light conveyed in the longer recension of the Slavonic pseudepigraphon through the expression "light out of light." He proposes that this imagery of light possibly rendered in the Greek Vorlage of 2 Enoch through the term $\varphi \tilde{\omega} \varsigma$, as in many other accounts that contain the Celestial Man ideology - might have an anthropomorphic significance. ${ }^{15}$ It is well known that the heavenly Anthropos traditions often play on the ambiguity of the $\varphi \omega \varsigma$ terminology that can designate either $\varphi \omega \tilde{\varsigma}$ "a man" or $\varphi \tilde{\omega} \varsigma$ "light," both pointing to the luminous and anthropomorphic nature of the Celestial Human. ${ }^{16}$ In view of these conceptual developments, Adoil can be understood in the Slavonic apocalypse as an anthropomorphic entity that is predestined to serve not only as the pattern of the visible creation but also as the blueprint of humanity. The possible 
"human" form of Adoil seems also reaffirmed in both recensions through references to his belly.

The anthropomorphic dimension of the $\varphi \omega \varsigma$ symbolism was also evident in the Hermetic and Gnostic cosmologies that also often play on the ambiguity of this terminology in their depiction of the Heavenly Man. In this respect it is intriguing that some Gnostic anthropogonies use expressions very similar to 2 Enoch by describing the Celestial Man "Adamas" as "a light which radiated from the light." ${ }^{17}$

\section{The anthropogony of 2 Enoch: Sophia and seven}

The enigmatic unfolding of the cosmogonic process in the Slavonic apocalypse receives further conceptual development in the account of the creation of Adam that follows this narration. Interestingly, the cosmogonic account of Adoil's disintegration in chapters 25-7 and the anthropogonic account of Adam's creation found in chapter 30 appear to be closely connected with each other, as some of Adam's qualities resemble some peculiar features of the great aeon.

One of the prominent features here is a parallel between the luminosity of Adoil and the luminosity of Adam. Thus, according to 2 Enoch 30.12, the prelapsarian Adam was a very special celestial being. The Slavonic apocalypse defines him as a second angel who was great and glorious. ${ }^{18}$

The designation of Adam as a "second angel" is also intriguing in light of previous scholarly suggestions that Adoil too appears to be envisioned in the text as an angel. ${ }^{19}$ In view of the possible angelic nature of the first aeon, Adam's designation as the second angel may have been conceived as a subtle link between the two characters by placing the patriarch in parallel with the Heavenly Man. Additional imagery found in the text seems to corroborate this connection. In this respect it is noteworthy that the account of Adam's creation ends with an arcane hymn about the two "substances" of humanity invisible and visible:

From invisible and visible substances I created man.

From both his natures come both death and life.

And (as my) image he knows the word like (no) other creature.

But even at his greatest he is small,

and again at his smallest he is great. ${ }^{20}$

In light of this juxtaposition of the invisible and the visible, it is worth noting that the descent of Adoil in both recensions of 2 Enoch 25.1 is rendered through similar terminology, as transition from an invisible into a visible condition: "And I commanded the lowest things: 'Let one of the invisible things descend visibly!' And Adoil descended, extremely large." ${ }^{21}$ 
Moreover, the aforementioned hymn makes an enigmatic juxtaposition between the invisible and visible substances of the Protoplast and the conditions of death and life, which possibly signify here the states of mortality and immortality: "From invisible and visible substances I created man. From both his natures come both death and life."

It is striking that Poimandres 15 offers a very similar cluster of traditions about the twofold nature of humankind, in which the immortal part is linked with the Celestial Man: "Because of this, unlike any other living thing on earth, mankind is twofold - in the body mortal but immortal in the essential man."22

All these parallels help to clarify the subtle correlations between Adoil and Adam, providing further insight into the relationships between 2 Enoch's cosmogony and anthropogony.

The unity of the cosmological and anthropological developments in the Slavonic apocalypse is also evident in the tradition about the sevenfold nature of humanity. The longer recension of 2 Enoch 30.8-9 recounts that Adam was created from seven "components" 23 and endowed with seven "properties/ faculties": ${ }^{24}$

And on the sixth day I commanded my wisdom to create man out of the seven components:

his flesh from earth;

his blood from dew and from the sun;

his eyes from bottomless sea;

his bones from stone;

his reason from the mobility of angels and from clouds;

his sinews and hair from grass of the earth;

his spirit from my spirit and from wind.

And I gave him 7 properties:
hearing to the flesh;
sight $\quad$ to the eyes;
smell $\quad$ to the spirit;
touch to the sinews;
taste to the blood;
to the bones - endurance;
to the reason - sweetness.

The creation of Adam from seven substances is important for our study. It is again reminiscent of the Hermetic and Gnostic developments where the sevenfold anthropogonic pattern is intertwined with the sevenfold cosmogony.

For example, in Poimandres 16-17 the following cryptic tradition can be found: 
Poimandres said: "This is the mystery that has been kept hidden until this very day. When nature made love with the man, she bore a wonder most wondrous. In him he had the nature of the cosmic framework of the seven, who are made of fire and spirit, as I told you, and without delay nature at once gave birth to seven men, androgyne and exalted, whose nature were like those of the seven governors ...

As I said, then, the birth of the seven was as follows. <Earth> was the female. Water did the fertilizing. Fire was the maturing force. Nature took spirit from the ether and brought forth bodies in the shape of the man. From life and light the man become soul and mind; from life came soul, from light came mind, and all things in cosmos of the senses remained thus until a cycle ended <and> kinds of things began to be." ${ }^{27}$

Here humanity's origin is traced to the seven spirits ${ }^{28}$ who are responsible for "giving birth" to the seven androgynous humans. ${ }^{29}$

It is also intriguing that in Poimandres 16-17 the sevenfold anthropogony corresponds to the sevenfold cosmology (wherein the seven proto-humans are correlated to the seven celestial governors'-planets called "administrators") and also to the "senses" or elements of nature and the human body. Thus a passage in Poimandres 9 tells about seven planetary "governors," applying to them the terminology of "circles":

The mind who is god, being androgyne and existing as life and light, by speaking gave birth to a second mind, a craftsman, who, as god of fire and spirit, crafted seven governors; they encompass

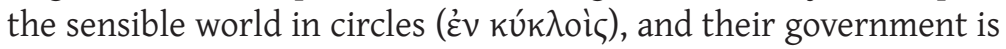
called faith. ${ }^{30}$

The symbolism of the planetary "circles" in this passage is reminiscent of the imagery in the Slavonic apocalypse. A tradition found in the longer recension of 2 Enoch 27.3-4 speaks of God creating seven great "circles" in the "foundation of light":

And I made a foundation of light around the water. And I created seven great circles inside it, and I gave them an appearance of crystal, wet and dry, that is to say glass and ice, and to be the circuit for water and the other elements. And I pointed out to each one of them his route, to the seven stars, each one of them in his own heaven, so that they might travel accordingly. And I saw how good it was. And I made a division between the light and between the darkness, that is to say, in the middle of the waters, this way and that way. And I said to the light that it should be day, and to the 
darkness I commanded that it should be night. And evening came, and again morning came, that is the first day. ${ }^{31}$

In this passage, the creation of the seven planetary circles and seven stars appears to be connected, as in the Corpus Hermeticum, with the sevenfold nature of primordial humanity. Our study will later show that in the account of Adam's creation in 2 Enoch 30, the list of the seven planets is given immediately before the account of the Protoplast's creation from the seven components. Here, as in the Hermetic literature, the seven "governors" of the heavens appear to be envisioned as the defining cosmological pattern that precedes the sevenfold nature of primordial humanity.

A similar correspondence between the sevenfold cosmology and the sevenfold anthropogony appears in several Gnostic texts, including the Apocryphon of John, where the seven components of Adam's body correspond to the seven anthropogonic agents associated with planetary spheres and responsible for the fashioning of the first human's body. ${ }^{32}$

Thus the Apocryphon of John unveils the identities of seven rulers and their role in the creation of the psychic body of Adam:

And the rulers created seven powers for (each of) them, and the powers created for themselves six angels for each one until they became 365 angels. And these are the bodies belonging with the names: the first <is> Athoth, he has a sheep's face; the second is Eloaiou, he has a donkey's face; the third is Astaphaios, he has a [hyena's] face; the fourth is Yao, he has a [serpent's] face with seven heads; the fifth is Sabaoth, he has a serpent's face; the sixth is Adonin, he had a monkey's face; the seventh is Sabbede, he has a shining fire-face. This is the sevenness of the week. ${ }^{33}$

... And he said to the authorities which attend him, "Come, let us create a man according to the image of God and according to our likeness, that his image may become a light for us." And they created through their respective powers in correspondence with the characteristics which were given. And each authority supplied a characteristic by means of the form of the image which he had seen in its psychic (form). He created a being according to the likeness of the first, perfect Man.

And they said, "Let us call him Adam, that his name may become a power of light for us." And the powers began (to create): the first one, Goodness, created a bone-soul; and the second, Providence, created a sinew-soul; the third, Divinity, created a flesh-soul; and the fourth, Lordship, created a marrow-soul; the fifth, Kingdom, created a blood-soul; the sixth, Envy, created a skin-soul; the seventh, Understanding, created a hair-soul. And the multitude of the 
angels attended him, and they received from the authorities the seven substances of the soul in order to create the proportions of the limbs and the proportions of the trunk and the proper working together of each of the parts. ${ }^{34}$

Here, as in the aforementioned Hermetic materials, the correspondence between the Heavenly Man and his "material" counterpart is mediated by the anthropogonic sevenfold pattern. Several other Gnostic texts also affirm this tradition of the seven androgynous anthropogonic "mediators." Thus, for example, On the Origin of the World 16-17 reads:

Seven appeared in chaos, androgynous. They have their masculine names and their feminine names ... These are the [seven] forces of the seven heavens of [chaos]. And they were born androgynous, consistent with the immortal pattern that existed before them, according to the wish of Pistis. ${ }^{35}$

Here again, as in the aforementioned passages from the Poimandres, the connection is made between the seven androgynes and the sevenfold pattern according to which they were "born." While the list of the corresponding celestial governing planets is not explicitly outlined in the versions of the Apocryphon of John, their authors knew these astral correlations. ${ }^{36}$

Roelof van den Broek summarizes the correspondences found in the several versions of the Apocryphon of John by offering the following juxtaposition of archons, powers, planets, and soul substances: ${ }^{37}$

$\begin{array}{llll}\text { Iaoth } & \text { Pronoia } & \text { Moon } & \text { Marrow } \\ \text { Eloaios } & \text { Divinity } & \text { Mercury } & \text { Bones } \\ \text { Astaphaios } & \text { Goodness } & \text { Venus } & \text { Sinews } \\ \text { Iao } & \text { Fire } & \text { Sun } & \text { Flesh } \\ \text { Sabaoth } & \text { Kingship } & \text { Mars } & \text { Blood } \\ \text { Adoni } & \text { Synesis } & \text { Jupiter } & \text { Skin } \\ \text { Sabbataios } & \text { Sophia } & \text { Saturn } & \text { Hair }\end{array}$

These correlations are thought-provoking as they show close similarities with the planetary list given in the creational narrative of the Slavonic apocalypse. It is also intriguing that in 2 Enoch this planetary list precedes almost immediately the rosters of the seven components and properties of Adam. Thus the longer recension of 2 Enoch 30.2-3 relates:

And on the fourth day I commanded: "Let there be great lamps on the heavenly circles." On the first, the highest circle, I placed the star Kronos; 
on the 2nd, <lower down, I placed> on the $3 \mathrm{rd}$

on the 4 th

on the 5 th

on the 6th

and on the 7th, the lowest
Afridit;

Arris;

the sun;

Zeous;

Ermis;

the moon. ${ }^{39}$

Although some Greek names on this planetary list appear to have been corrupted during the long transmission history of the Slavonic apocalypse,$^{40}$ it is not difficult to restore their original forms.

The corrupted Greek names given in the list correspond to the following planets: ${ }^{41}$

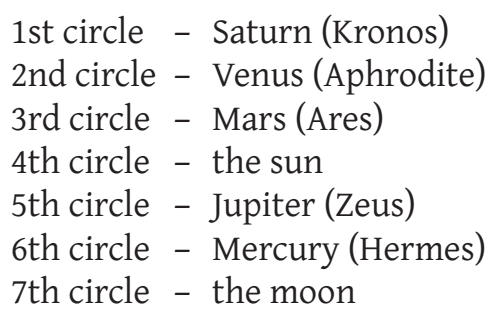

This list is reminiscent of the planetary list of the Archons provided by van der Broek, although it misplaces Jupiter and Venus ${ }^{42}$ and reverses the order of planets, starting with Saturn (Kronos) and concluding with the moon. Van den Broek notes that, according to Origen's Against Celsus 6.31, this reversal of the planetary order was part of the Ophites' cosmological system. ${ }^{43}$

The cluster of traditions surrounding the creation of the Protoplast in the Slavonic apocalypse, similarly to the Gnostic and Hermetic materials, points to the unity of the cosmological and anthropogonic speculations which are tied together through the distinctive sevenfold patterns. Although the applications of the sevenfold patterns in relation to humanity have been known in various Hellenistic milieux from the most ancient times, the peculiar nature of these developments in the Slavonic apocalypse appears to draw them closer to the variants found in later Hermetic and Gnostic texts.

In this respect another, even more striking parallel between the account of creation in 2 Enoch 30 and the Gnostic materials should be mentioned. In the longer recension ${ }^{44}$ of 2 Enoch 30.8 the deity commanded his Wisdom ${ }^{45}$ to create man out the seven components. ${ }^{46}$ Scholars have previously noted the parallels between this role of Wisdom (Gk. Sophia) in the creation of the first human in the Slavonic apocalypse and the Gnostic texts. ${ }^{47}$ Some scholars even suggested that the Sophia tradition in 2 Enoch 30 might be an early Jewish prototype of the later Gnostic developments. ${ }^{48}$

Although in the Poimandres' version of the anthropogonic myth Nature is responsible for the creation of the seven androgynous beings, in some Nag 
Hammadi materials it is Sophia ("Wisdom") ${ }^{49}$ that generates the immortal sevenfold pattern, the portentous blueprint later imitated in the seven androgynous archons..$^{50}$ She is also one of the seven "powers" - the entity corresponding to the name of archon Sabbataios on the lists of rulers in the Apocryphon of John. It is intriguing that, as in the Slavonic apocalypse where wisdom is in charge of the sevenfold pattern, in Gnostic and some other related materials Sophia also takes charge of the seven entities responsible for the creation of the first human.

Thus On the Origin of the World 16-17 reads:

Seven appeared in chaos, androgynous ... And they were born androgynous, consistent with the immortal pattern that existed before them, according to the wish of Pistis (Sophia): so that the likeness of what had existed since the beginning might reign to the end. ${ }^{51}$

Here Wisdom (Sophia) is put in charge of the "immortal" sevenfold pattern according to which the seven androgynous archons are brought into existence. The Hypostasis of the Archons 3-4 offers a very similar tradition that puts Sophia in charge of the sevenfold pattern which lays the basis for the creation of humankind..$^{52}$

The Sophia tradition found in the Slavonic apocalypse may indeed be one of the most veiled conceptual developments in the text. The true extent of this enigmatic demiurgic entity assisting the deity in his creation remains shrouded in mystery. It is possible that in 2 Enoch Sophia is linked not only with fashioning the sevenfold human body but also with generating the seven celestial "governors." It is intriguing that in chapter 48 Enoch, while outlining the process of the creation of celestial bodies, mentions that they were "fixed" by God's own wisdom..$^{53}$

In concluding this section dealing with protological developments, we should again highlight the prominence of the sevenfold patterns in the text's cosmological and anthropological developments. While many sevenfold list found in the Slavonic apocalypse appear to have been irreparably corrupted during the text's long journey through various religious and linguistic milieux, these sevenfold patterns represent the paramount link connecting the protological narrative with its eschatological counterpart, where the sevenfold blueprint will again play a vital role.

\section{THE AEON AFTER CREATION}

The final aeon as the reverse anthropogony

It is time to return to the tradition of the primordial aeon in the Slavonic apocalypse. The aforementioned primeval account of creation, narrated by God in 
chapters 25 and 26 of the Slavonic pseudepigraphon, is invoked in abbreviated form in the subsequent chapters of the text where Enoch unveils to his sons the knowledge he received during his celestial trip. There the reader also encounters some additional cosmological details pertaining not only to the beginning of creation but also its final destiny.

Chapter 65 of 2 Enoch deals with the final instructions the translated hero of the faith relates to humanity immediately before his second and final departure to heaven. The final place of this revelation among the other mysteries conveyed by Enoch to humankind during his short visit underlines the significance of this disclosure. In many ways it appears to be set in parallel with the account of the Lord's own instructions about the secrets of creation, which Enoch also received from the Deity at the end of his heavenly trip after the preliminary revelations conveyed to him by his psychopomps and angel Vereveil.

This enigmatic revelation is intriguing not only in the format of its delivery which parallels the secrets of creation revealed by the Lord in previous chapters 25 and 26 but also in its peculiar content which in many ways mirrors the familiar conceptual framework of the protological revelation. The shorter recension of 2 Enoch 65.1-11 reads:

Listen, my children! Before all things existed, (and) before all creation came about, the Lord established the age of creation, and after that he created all his creation, visible and invisible ... When the whole creation which the Lord has created, shall come to an end, and when each person will go to the Lord's great judgment, then the time periods will perish, and there will be neither years nor months nor days, and hours will no longer be counted; But they will constitute a single age. ${ }^{54}$ And all the righteous, who escape from the Lord's great judgment, will be collected together with the great age. And <the age> at the same time will unite with the righteous, and they will be eternal. And there will be among them neither weariness nor suffering nor affliction nor expectation of violence nor the pain of the night nor darkness. But they will have a great light for eternity, <and> an indestructible wall, and they will have a great paradise, the shelter of an eternal residence. How happy are the righteous who will escape the Lord's great judgment, for their faces will shine forth like the sun." ${ }^{55}$

The patriarch begins his narration with references to the familiar theme of the primeval aeon already encountered in chapter 25 . These protological events are then set in parallel with the chain of eschatological actions that, according to the authors of the apocalypse, will reintegrate the remnant of the creation - an elite group of humans - into a single aeon which will collect all the righteous of the world. ${ }^{56}$ The final consummation of all creation 
into a single aeon recalls the initial protological disintegration of Adoil who once gave birth to the multiplicity of created forms. ${ }^{57}$ It appears that the final consummation of the created order "reverses" its protological unfolding in such a way that reintegration into the final aeon invokes memory of the disintegration of the primeval aeon Adoil. In comparison with the cosmogonic character of the primeval aeon, the last aeon though has distinctive anthropogonic features. In this respect it seems that the reverse cosmogenesis of the last days also presupposes the reversal of the anthropogonic process in the course of which the righteous of the world and their exemplar, the seventh antediluvian hero, inherit some qualities of the prelapsarial Adam and some distinctive features of his cosmogonic blueprint, the primordial aeon Adoil. Here, unlike in many other Jewish accounts of the last days, the eschatological humanity does not simply regain the original state of the Protoplast, instead returning to the condition of the immaterial Anthropos, that is, the anthropomorphic primordial aeon, Adoil. The text also seems to suggest that the righteous Enoch, translated to heaven and transformed into a luminous celestial creature, represents the first fruit of this eschatological aeon that will eventually gather all the righteous into one single entity.

\section{The beloved seventh}

It has already been noted that chapter 65 of the Slavonic apocalypse provides a striking description of the final age. Yet some details about the eschatological entity can also be found in the longer recension of the following chapter of 2 Enoch (chapter 66) where the seventh antediluvian patriarch tells his children about the sevenfold nature of the final aeon. 2 Enoch 66.6-8 relates:

Walk my children in long-suffering ... having love for one another, until you go out from this age of suffering, so that you may become inheritors of the never-ending age. How happy are the righteous who shall escape the Lord's great judgment; for they will be made to shine seven times brighter than the sun. For in that age everything is estimated sevenfold - light and darkness and food and enjoyment and misery and paradise and tortures. ${ }^{58}$

This tradition about the sevenfold nature of the final age is intriguing in that it recalls the familiar cluster of the sevenfold patterns permeating the anthropogony of the Slavonic apocalypse - the feature discussed in detail in the first part of our investigation.

In light of the "anthropogonic" nature of the final age - described in the Slavonic apocalypse as the final abode of perfected humanity, the gathering place of the righteous - invocation of the details of the Protoplast's creation does not seem entirely inappropriate. Unlike some Gnostic texts where the 
seven elements of Adam's corporeality are linked to the seven infamous anthropogonic agents responsible for fashioning Adam's psychic body, in the Slavonic apocalypse Wisdom creates, out of seven properties, the perfect human being whom the text describes as the great and glorious celestial creature.

The sevenfold nature of the final age inhabited by perfected humanity thus invokes the perfect sevenfold nature of the Protoplast before his fall. This connection seems to be further strengthened in the initial verses of chapter 65 where Enoch relates to his children the mystery of the final aeon. There some peculiar details of the Protoplast's creation are invoked, including the elements of the sevenfold pattern of his "properties."

Thus in 2 Enoch 65.1-2 the patriarch says the following:

Listen, my children! Before ever anything existed, and before ever any created thing was created, the Lord created the whole of his creation, visible and invisible. And however much time there was went by. Understand how, on account of this, he constituted man in his own form, in accordance with a similarity. And he gave him

$\begin{array}{ll}\text { eyes } & \text { to see, } \\ \text { and ears } & \text { to hear, } \\ \text { and heart } & \text { to think, } \\ \text { and reason } & \text { to argue. }\end{array}$

And the Lord set everything forth for the sake of man, and he created the whole of creation for his sake..$^{59}$

It is interesting that in this passage the details of the primordial cosmogony and anthropogony are closely tied together.

The seventh antediluvian hero's peculiarly selective memory, which strives to bring together the account of the great aeon Adoil and the story of the Protoplast's creation, points to the importance of this conceptual correlation for understanding the mystery of the sevenfold final aeon, which is predestined to shelter transformed humanity now returning to its original condition.

Further, it appears that the connection of the seventh antediluvian hero with this sevenfold pattern of the final age is not coincidental either. It is possible that here, as in many other Enochic texts, the seventh human being is envisioned as the first fruit of perfected humanity predestined to return to its original prelapsarian condition. The proleptic account of this portentous return is described in detail in chapter 22 of the Slavonic apocalypse where the seventh antediluvian hero undergoes a dramatic metamorphosis that transforms him into a glorious celestial being - a creature identical in its luminous nature to the Protoplast.

Therefore it does not seem coincidental that the return to the original state of humankind, once endowed with the sevenfold pattern of "components" and "properties," is executed through the seventh human being. 
The portentous place of the seventh human, overshadowed by his unique role in restoring the condition of the first human, is known in many ancient interpretive traditions. In this respect, it is noteworthy that in the story of the seventh antediluvian hero one encounters another, even more ancient, Mesopotamian version of the sevenfold anthropogony, namely, the primordial myth about seven proto-humans, known in Mesopotamian pantheons as apkallu..$^{60}$ The apkallu ${ }^{61}$ appear to be envisioned as agents responsible for bringing humanity to perfection through education and transmission of celestial knowledge. In a way, these seven apkallu might be seen as the spiritual entities standing behind the seven antediluvian heroes. Scholars have previously noted the connections between the apkallu traditions and the Sumerian King List - the roster where a prototype of Enoch, the seventh antediluvian king Enmeduranki, plays an important role. ${ }^{62}$ The Enmeduranki traditions often describe the seventh antediluvian hero as the "beloved" of the great gods. ${ }^{63}$ This tradition about the special place of the seventh human as the chosen vessel of the upper realm was not lost or forgotten during the long theological history of the seventh antediluvian hero. Thus even later rabbinic materials often apply the same title to Enoch, designating him as the "Beloved Seventh." ${ }^{4}$

\section{Enoch as the Righteous One}

It does not seem coincidental that the portentous revelation about the final aeon of the righteous comes from the mouth of the seventh antediluvian patriarch, the hero known in Jewish lore for his exemplary righteousness. In light of this connection, the motif of Enoch's righteousness should be examined more closely. The epithet "righteous man" becomes an important designation of the seventh antediluvian hero already in the beginning of his story, where his righteousness is juxtaposed with the wickedness of the antediluvian generation and the transgressions of the Watchers.

Already in the very first verses of one of the earliest Enochic booklets, the Book of the Watchers, the patriarch is defined as a righteous man. ${ }^{65}$ In 1 Enoch 15.11 the same designation comes now from the mouth of the Deity himself: "And he answered me and said to me with his voice: Hear! Do not be afraid, Enoch, (you) righteous man and scribe of righteousness." ${ }^{66}$ Besides the patriarch's exemplary behavior, which allowed him to become the paragon of righteousness for future generations, this passage also points to another important office of the seventh antediluvian hero as the teacher of righteousness - an office in which he was desperately attempting to rescue and sustain the moral and cosmological order of the antediluvian world by delivering oracles of doom and calls to repentance which he received from God and angels. ${ }^{67}$ Early Enochic materials, 1 Enoch 12.4 and 15.11, thus repeatedly define him as the scribe of righteousness. 
It is quite possible that Enoch's connection with the eschatological destiny of the righteous may be already ascertained in the early Enochic writings. According to 1 Enoch, the patriarch travels to the enigmatic location "the paradise of righteousness," which might represent here another designation for the eschatological gathering of the righteous.

\section{Enoch-Metatron as the foundation}

It has already been noted that, in the protological account dealing with the creation of the world, Adoil is depicted as the foundation of visible things, both earthly and heavenly, including the very seat of the Deity, His Throne. In view of the aforementioned parallelism between the descriptions of the first and last aeons, it appears that the "eschatological age" is also connected with the idea of the foundation. Although the description of the eschatological gathering of the righteous does not directly refer to this entity as the foundation, the idea is evident in the text through several implicit details.

In commenting on the identification of the final aeon with the righteous, Moshe Idel notes that in Jewish mysticism the righteous are often portrayed as the cosmological foundation of the world. ${ }^{68} \mathrm{He}$ points to the tradition found in $b$. Hag. 12b, where the righteous are depicted as the cosmological foundation of the world: ${ }^{69}$

It is taught: R. Jose says: Alas for people that they see but know not what they see, they stand but know not on what they stand. What does the earth rest on? On the pillars, for it is said: Who shaketh the earth out of her place, and the pillars thereof tremble ... But the Sages say: [The world] rests on twelve pillars, for it is said: He set the borders to the peoples according to the number [of the tribes] of the children of Israel. And some say seven pillars, for it is said; she hath hewn out her seven pillars. ${ }^{70} \mathrm{R}$. Eleazar b. Shammua says: [It rests] on one pillar, and its name is "Righteous," for it is said: But "Righteous" is the foundation of the world..$^{71}$

It is no coincidence that the "revealer" and the "first fruit" of the eschatological aeon - the righteous Enoch - also appears to be conceived in some pseudepigraphical and rabbinic accounts as the pillar or foundation of the world.

As has already been noted, early Enochic booklets seek to highlight the contrast between the righteousness of Enoch and the unrighteousness of the antediluvian generation, in which the Watchers' interference causes moral and cosmological collapse leading the environment and the human race toward an imminent catastrophe. In the protological mishap leading to the annihilation of the earth's inhabitants in the waters of the Flood, one might 
see a proleptic reenactment of the eschatological collapse of the last days where the seventh antediluvian hero is also predestined to play an important role. In this catastrophic chain of events affecting the whole fabric of creation, Enoch can be seen as the righteous one who attempts to sustain the created order, in many ways serving as the pillar of the antediluvian world. This important role of the seventh antediluvian hero as the sustainer and protector of creation is reaffirmed in the Book of Jubilees that depicts the patriarch as the cosmic dam against the waters of the Flood. ${ }^{72}$

Enoch's role as an entity sustaining the world was not forgotten in later Jewish materials. Idel's research identifies an important tradition, preserved in later Jewish mysticism, that portrays the seventh antediluvian hero as the foundation which sustains the world: "the righteous is the foundation of the world. For [the sake of] one [single] righteous the world is maintained and it is Enoch the son of Yared." ${ }^{3}$ It is apparent that the author(s) of this tradition, which might stem from the early Enochic literature, were informed by the extra-biblical roles and actions of the seventh patriarch, who served there as the pillar of the world attempting to sustain creation's moral and cosmological order in the turmoil of the antediluvian generation.

This understanding of Enoch as the foundation of the world is not atypical in Jewish mystical lore where the patriarch's heavenly counterpart, the supreme angel Metatron, was traditionally understood as the force sustaining the world. These cosmological functions were exhibited first in Metatron's role as the governor or the prince of the world (שר העולם), an office already discernable in 2 Enoch $^{75}$ and further developed in Hekhalot mysticism, including traditions found in Sefer Hekhalot. ${ }^{76}$ It is intriguing that Enoch-Metatron's governance of the world includes not only administrative functions but also the duty of the physical sustenance of the world. Moshe Idel refers to the treatise The Seventy Names of Metatron where the angel and God seize the world in their hands. ${ }^{77}$ This motif of the Deity and his vice-regent grasping the universe in their cosmic hands invokes the conceptual developments found in the Shiur Qomah and Hekhalot materials, where Enoch-Metatron possesses a cosmic corporeality comparable to the physique of the Deity and is depicted as the measurement of the divine Body. ${ }^{78}$

In light of these traditions, it seems possible that already in the Slavonic apocalypse the authors try to portray Enoch as the eschatological foundation of the world ${ }^{79}$ who already participates in the final aeon of the righteous and can thus be seen as the first fruit of this eschatological gathering. In this respect, like Adoil who anticipates the protological aeon that gives to all creation its beginning, Enoch too anticipates the future eschatological aeon when the creation will collapse and all the righteous will be united together. Both Adoil and Enoch can therefore be seen as outstanding exemplars preordained to manifest the protological and eschatological states through their ontological conditions, thus serving as "personifications" of these aeons. Both heroes are also united by the quality of their luminosity that serves as an important 
sign of the beginning and end of time. Here, as in the Lurianic Kabbalah, the primordial divine light, dispersed during Adoil's disintegration and then the Fall of the Protoplast, must be restored by the efforts of the righteous who will become a new eschatological vessel of the uncreated light.

\section{Enoch as the Vessel of Light}

2 Enoch 66.11 describes the condition of the righteous in the final aeon, depicting them as luminous beings: "How happy are the righteous who will escape the Lord's great judgment, for their faces will shine forth like the sun." ${ }^{80}$ This tradition about righteous humans emitting light seems to be tied implicitly in the text to the story of its revealer, the seventh antediluvian patriarch, who himself underwent several chapters earlier a dramatic luminous transformation.

The passage may thus suggest that Enoch - depicted in chapter 22 as undergoing a luminous metamorphosis before the Face of God ${ }^{81}$ which turns him into a shining celestial creature - becomes the very first fruit of this future aeon where all righteous persons will eventually regain the condition of luminosity. The eschatological luminosity here points to the protological condition of Adoil and, more importantly, to the incorruptible luminous state of the Protoplast, a condition humanity lost after Adam's fall. ${ }^{82}$

Here the righteous of the world are envisioned as the "gatherers" of divine light, namely, those who repair both cosmogonic and anthropogonic vessels of the primordial light by turning themselves into the luminous vessel of the last days. ${ }^{83}$ One might see in this mysterious aeonic gathering of the transformed humans the eschatological refashioning of the luminous corporeality of the Heavenly Man, ${ }^{84}$ who is restored by the efforts of righteous souls now able to reconstitute the particles of divine light into a single aeon..$^{85}$

\section{The demiurgic role of Enoch}

Although the Slavonic apocalypse insists on Deity's role as the sovereign ${ }^{86}$ Creator of the universe, scholars have previously ${ }^{87}$ noted that this emphasis on the sovereignty of the Deity in creation does not seem entirely monolithic in the Slavonic text if one considers the Deity's decision to share the secrets of creation $^{88}$ that He did not explain even to the angels.

Here, therefore, one might discern a delegation of the demiurgic function to God's vice-regent, a motif that will play an important role in the Metatron traditions in Sefer Hekhalot and the Zohar. In these texts, the letters on the crown given to Metatron attest to his partaking in the works of creation. Some scholars have noted that the link between Metatron and the "secrets of creation" manifested in the Hekhalot tradition may witness to his role as a demiurge, or 
at least to his participation in the work of creation. ${ }^{89}$ Jarl Fossum draws attention to the tradition attested in Genesis Rabbah 5:4 on Genesis 1:9, according to which "the voice of the Lord became a guide (מטטרון) to the waters, as it is written: "The voice of the Lord is over the waters." "91 Fossum proposes that this passage might refer to the Metatron's demiurgic role. ${ }^{92} \mathrm{He}$ also suggests that while the depiction of Metatron in Sefer Hekhalot is not demiurgic, it points to the matrix of ideas out of which the Gnostic concept of the demiurge possibly arose..$^{93}$ The beginning of the tendency towards Enoch-Metatron's demiurgic profile might already be detected in 2 Enoch, a text which puts great emphasis on Enoch's knowledge of the secrets of creation and which sometimes describes Enoch as if he were a divine being. ${ }^{94}$

In this respect, Enoch's demiurgic function - which is hinted at by his access to the esoteric knowledge of the final aeon and his revelation of this knowledge to the people of the earth - might be set in parallel to the demiurgic function of Adoil, who is depicted as the revealer of the primordial aeon.

\section{FINAL REMARKS}

In later Metatron lore, Enoch-Metatron is portrayed as the perfector of human souls who, like Abatur in the Mandaean tradition, is responsible for the progress of human souls ${ }^{95}$ to their final destiny. ${ }^{96}$ Both the Babylonian Talmud ${ }^{97}$ and Hekhalot literature ${ }^{98}$ hint at this mysterious office of Metatron when they depict him as the teacher of Torah to the souls of deceased children. ${ }^{99}$

In view of our previous investigation, it appears that this later Metatron's role as the "captain" of souls ${ }^{100}$ might already be hinted at in 2 (Slavonic) Enoch via the translated hero's enigmatic participation in the economy of the eschatological gathering of human souls in the final aeon of the righteous. ${ }^{101}$

This promise of the final gathering of righteous souls into a single luminous entity gives us hope that the aeonic vessels of primordial light, shattered in the beginning, will be eventually restored at the end of time.

\section{NOTES}

1. The unique details of this cosmogonic account have been previously noted by scholars. See Orlov (2007: 175-95).

2. Scholem (1991: 98-101); Idel (2005: 75).

3. The longer recension, while preserving the general narrative structure of the shorter one, supplies some additional details. The longer recension of 2 Enoch 25 reads (Andersen 1983: 144): "And I commanded the lowest things: 'Let one of the invisible things descend visibly!' And Adoil descended, extremely large. And I looked at him, and, behold, in his belly he had a great light. And I said to him, 'Disintegrate yourself, Adoil, and let what is born from you become visible.' And he disintegrated himself, and there came out a very great light. And I was in the midst of the [great] light. And light 
out of light is carried thus. And the great age came out, and it revealed all the creation which I had thought up to create. And I saw how good it was. And I placed for myself a throne, and I sat down on it. And then to the light I spoke: 'You go up higher (than the throne), and be solidified [much higher than the throne], and become the foundation of the higher things.' And there is nothing higher than the light, except nothing itself. And again I bowed (?) myself and looked upward from my throne."

4. Andersen 1983: 145.

5. Much scholarship has been devoted to clarifying the etymology of the enigmatic name of the great aeon. Many scholars consider the name to provide an important clue for understanding the origins of the text. Charles (1913, 2:445) suggests that Adoil might be derived from the Hebrew יד אל, translated as the "hand of God." Philonenko (1969: 114) supports this etymology, pointing to some Egyptian parallels in which "les premières créatures naissent du liquide séminal que le démiurge solitaire avait fait jaillir au moyen de sa main." Cry (1940: 201) suggests understanding Adoil as stemming from אור אור אל "the light of God." In his opinion,," were altered. Resh was read as daleth; waw was transposed. These alterations produced Adoil. Vaillant (1976: xi) suggests that the name might be derived from the Hebrew word with a suffix, "his eternity, his aeon." Scholem (1978: 73) criticizes this rendering, arguing that the Hebrew word עד cannot carry a pronominal suffix. According to Scholem (1958: 252) Adoil derives from Sadoqil. Milik (1976: 113) considers the name Adoil "a Greek and Semitic hybrid: Hades + El". Quispel derives it from Adonai-el, where the first element is the circumlocution for the Tetragrammaton (Fossum 1985: 288). I have previously proposed (Orlov 2005: 199) that the name Adoil might be connected with "El Gadol" (the Great God) - a designation for the primordial upper foundation in the creational narrative of the Book of Zohar (Zohar 1.17b). In this respect it is intriguing that in 2 Enoch Adoil is called "the large one" or "the great one."

6. Sokolov (1910: 25).

7. Both recensions stress that Adoil's disintegration provides an important foundation on which the divine Throne is established. The seat of the Deity thus serves here as the portentous locale from which God supervises the unfolding creation. The Throne plays an important role in the process of creation, being envisioned as the center of the created world.

8. His revelations, however, encompass not verbal but rather "ontological" disclosure, conveyed through the act of changing his nature. This mode of revelation is very important for our subsequent analysis of Enoch's role as the revealer and his "ontological" participation in the disclosure of the eschatological aeon.

9. "And Adoil descended, extremely large. And I looked at him, and, behold, in his belly he had a great light ... there came out a very great light. And I was in the midst of the [great] light. And light out of light is carried thus" (Andersen 1983: 144).

10. See, for example, MacRae (1970: 90).

11. In his comments on the notion of the Celestial Man in the Poimandres and the Apocryphon of John, van den Broek (1998: 15) notes that "both texts know the important notion of a heavenly Man - a notion that has to be explained through its Jewish background." Van den Broek traces the origins of this concept to Ezekiel 1:26 where the prophet saw the Glory of God in the shape of a man. He then suggests that Ezekiel 1:26 "and a specific interpretation of the creation of man in Genesis eventually led to the myth of the heavenly Man."

12. Poimandres 12 (Copenhaver 1995: 3): "Mind, the father of all, who is life and light, gave birth to a man like himself whom he loved as his own child. The man was most fair: he had the father's image; and god, who was really in love with his own form, bestowed on him all his craftworks."

13. On the Gnostic variants of this myth, see Quispel (1953: 211-15); Gilhus (1985: 48ff). 
14. Poimandres 16 (Copenhaver 1995: 4): "Poimandres said: 'This is the mystery that has been kept hidden until this very day. When nature made love with the man, she bore a wonder most wondrous. In him he had the nature of the cosmic framework of the seven, who are made of fire and spirit, as I told you, and without delay nature at once gave birth to seven men, androgyne and exalted, whose natures were like these of the seven governors."

15. Fossum (1985: 289-90) observes that "Adoil is thus the prime cosmogonic agent, since he is the primordial phos, or - rather - the archetypal phos, which means 'man' as well as "light."

16. On the $\varphi \omega \varsigma$ traditions, see Quispel (1980: 6-7); Fossum (1985: 280; 1995: 16-17); Copenhaver (1995: 109).

17. Gospel of the Egyptians IV 61.8-10 (Bohlig et al. 1975: 93): "For this one, Adamas, is a light which radiated from the light; he is the eye of the light." Cf. also On the Origin of the World 5 (Layton 1989: 2.31): "Now the eternal realm (aeon) of truth has no shadow outside it, for the limitless light is everywhere within it. But its exterior is shadow, which has been called by the name 'darkness.' From it, there appeared a force, presiding over the darkness. And the forces that came into being subsequent to them called the shadow "the limitless chaos."

18. 2 Enoch 30.11-12 (Andersen 1983: 152): "And on the earth I assigned him to be a second angel, honored and great and glorious. And I assigned him to be a king, to reign on the earth, and to have my wisdom. And there was nothing comparable to him on earth, even among my creatures that exist."

19. Thus, for example, Fossum (1985: 287) observes that in the Adoil account: "the creation of the light has now become the result of its origination from an angelic being, whose stomach issues the light."

20. 2 Enoch 30.10, longer recension (Andersen 1983: 152).

21. 2 Enoch 25.1, longer recension (Andersen 1983: 144).

22. Copenhaver (1995: 3).

23. A similar list of components is found also in the Latin Life of Adam and Eve which offers a tradition of Adam's creation from the eight parts. Thus, the Latin Vita 37 [55] (Anderson \& Stone 1999: 96E) reads: "It must be known that the body of Adam was formed of eight parts. The first part was of the dust of the earth, from which was made his flesh, and thereby he was sluggish. The next part was of the sea, from which was made his blood, and thereby he was aimless and fleeing. The third part was of the stones of the earth, from which his bones were made, and thereby he was hard and covetous. The fourth part was of the clouds, from which were made his thoughts, and thereby he was immoderate. The fifth part was of the wind, from which was made his breath, and thereby he was fickle. The sixth part was of the sun, from which were made his eyes, and thereby he was handsome and beautiful. The seventh part was of the light of the world, from which he was made pleasing, and thereby he had knowledge. The eighth part was of the Holy Spirit, from which was made his soul, and thereby are the bishops, priests, and all the saints and elect of God." On the Adam Octipartite tradition attested in Latin, Old Irish and Slavonic materials, see Jagic (1893: 44-7); Förster (1907-8: 477529; 1921: 47-8); McNamara (1975: 21-3); Böttrich (1995); Macaskill (2007: 201).

24. The origin of this tradition of the seven elements of human nature can be traced to Plato's Timaeus 73B-76E. On these conceptual developments see van den Broek (1996: 75ff).

25. Although the lists of "properties" and "components" mentioned in 2 Enoch 30 appear to have been heavily corrupted during the text's long transmission history, they are reminiscent of the lists of the planetary melothesia found in Ptolemy's Tetrabiblos 3.12 (Robbins 1940: 319-20), where seven planets are put in correspondence with human "properties/faculties" (sight, touch, taste, smell, speech, thought etc.) and with the 
"components" (bones, sinews, flesh, etc.) of the human body: "Saturn is lord of the right ear, the spleen, the bladder, the phlegm, and the bones; Jupiter is lord of touch, the lungs, arteries, and semen; Mars of the left ear, kidneys, veins, and genitals; the sun of the sight, the brain, heart, sinews and all the right-hand parts; Venus of smell, the liver, and the flesh; Mercury of speech and thought, the tongue, the bile, and the buttocks; the moon of taste and drinking, the stomach, belly, womb, and all the lefthand parts." Scholars noted that although Ptolemy's compendium "is perhaps the best known of its kind, his list of correspondences between planets and faculties of the human body by no means goes back to Ptolemy's own invention. Such lists most probably stem from Hellenistic Egypt and can be traced back as far as the second century B.C.E." (Toepel 2005: 235). On the planetary melothesia, see also Bouché-Leclercq (1899: 319-25); Roscher (1902: 3:2535-6); Touwaide (1998: 5:873). The Jewish pseudepigraphical writings are also cognizant of the sevenfold system of human properties/ faculties. Thus, The Testament of Reuben 2.3-8 (Kee 1983: 782) provides a very similar cluster of traditions when it tells about seven spirits which were given to the protoplast at creation: "And seven other spirits are given to man at creation so that by them every human deed (is done). First is the spirit of life, with which man is created as a living being. The second is the spirit of seeing, with which comes desire. The third is the spirit of hearing, with which comes instruction. The fourth is the spirit of smell, with which is given taste for drawing air and breath. The fifth is the spirit of speech, with which comes knowledge. The sixth is the spirit of taste for consuming food and drink; by it comes strength, because in food is the substance of strength. The seventh is the spirit of procreation and intercourse, with which come sins through the fondness for pleasure." For a discussion of these traditions, see Toepel (2005: 235ff).

26. Sokolov (1910: 29-30).

27. Copenhaver (1995: 4).

28. On the Christian traditions of seven "first created" spirits, or the so-called protoctists, see Bucur (2009: 31-2, 38-9, 56-8, 69-70, 97-9, 135-8).

29. The tradition about the seven spirits or angels responsible for the origin of the humankind is also found in Irenaeus' account of Saturnilus' teaching. Cf. Irenaeus, Against Heresies 1.24.1.

30. Nock and Festugière (1954-60: 1:9); Copenhaver (1995: 2).

31. Andersen (1983: 146).

32. Scholars have previously noted that "the easiest general clue to the identity of Archons lies in the sevenfold lists. These are given in the several versions of the document that have survived, in almost identical form - in the Berlin Codex version (BG 41,16) and in the Codex II version from Nag Hammadi (II 59,26). In the BG version they are called 'the hebdomad of the week,' which seems to invite us to read them as the planetary powers of the successive days of the week" (Welburn 1978: 242).

33. Apocryphon of John II 11.23-35 (Waldstein \& Wisse 1995: 71-3).

34. Apocryphon of John II 15.1-23 (Waldstein \& Wisse 1995: 87-93). Cf. another version of this anthropogonic myth which is reflected in On the Origin of the World 78-9 (Layton 1989: 2:65): "Since that day, the seven rulers have fashioned (plassein) man with his body resembling their body, but his likeness resembling the man that had appeared to them. His modeling (plasma) took place by parts, one at a time. And their leader fashioned the brain and the nervous system. Afterwards, he appeared as prior to him. He became a soul-endowed (psychikos) man. And he was called Adam, that is, 'father,' according to the name of the one that existed before him."

35. Layton (1989: 2:37).

36. See Welburn (1978: 242). Cf. also Waldstein and Wisse (1995: 88-111).

37. It should be noted that van den Broek's chart of the correspondences between the Archons and the planets is based on Welburn's reconstruction. Welburn uses for his 
reconstruction the planetary lists found in Pistis Sophia, Origen and other materials (1978: 244).

38. Van den Broek (1996: 76). It is noteworthy that the five elements mentioned here (bones, sinews, flesh, blood, and hair) are also mentioned in the two lists found in 2 Enoch 30.

39. Andersen (1983: 148-50). It should be noted that the tradition of the seven planetary spheres is also mentioned in 2 Enoch 27.3 (Andersen 1983: 146), where the deity creates seven great circles: "And I made a foundation of light around the water. And I created seven great circles inside it, and I gave them an appearance of crystal, wet and dry, that is to say glass and ice ... And I appointed out to each one of them his route, to the seven stars, each one of them in his own heaven, so that they might travel accordingly."

40. In this respect Andersen notes that the planetary "scheme could be no better than a garbled Almagest by some uninformed individual" (1983: 149, n. b).

41. Cf. Against Celsus 6.22 (Chadwick 1953: 334): "They associate the first with Kronos (Saturn), taking lead to refer to the slowness of the star; the second with Aphrodite (Venus), comparing her with the brightness and softness of tin; the third with Zeus (Jupiter), as the gate that has a bronze base and which is firm; the fourth with Hermes (Mercury), for both iron and Hermes are reliable for all works and make money and are hard-working; the fifth with Ares (Mars), the gate which as a result of the mixture is uneven and varied in quality."

42. The planetary list found in 2 Enoch appears to also deviate from the traditional list based on the ancient view of planets' distance from the earth - Saturn, Jupiter, Mars, Sun, Venus, Mercury, Moon (Chadwick 1953: 335, footnote 2).

43. Van den Broek (1996: 70); Against Celsus 6.31 (Chadwick 1953: 347): "And they say that the star Saturn is in sympathy with the lion-like Archon." On the identification between Kronos/Saturn and Ialdabaoth see also Bousset (1907: 351-5).

44. The shorter recension of 2 Enoch 30.8 presents the tradition about Wisdom's creation of man in very abbreviated form, without any references to the pattern of seven (Andersen 1983: 151): "When I had finished all this, I commanded my wisdom to create man."

45. It should be mentioned that already in Wisdom of Solomon 9:2 and 10:1-2, Wisdom is responsible for the formation, protection, deliverance, and strengthening of the protoplast: "[who] by your wisdom have formed humankind," "Wisdom protected the first-formed father of the world, when he alone had been created; she delivered him from his transgression, and gave him strength to rule all things." Cf. also 2 Enoch 30.12 (Andersen 1983: 152): "And I assigned him to be a king, to reign on the earth, and to have my wisdom."

46. Already in Proverbs 9:1, Wisdom is associated with the sevenfold cosmic structure: "Wisdom has built her house, she has hewn her seven pillars." Yet in 2 Enoch 30 and Gnostic cosmogonies this sevenfold pattern is applied to the creation of Adam's body. George MacRae (1970: 93) suggests that "in the cosmogonic works it is conceivable that the seven Archons or planetary deities resulting from Sophia's fall are an application of the image in Proverbs 9:1, although the passage is certainly not the primary source of the idea of a sevenfold Demiurge."

47. See, for example, MacRae (1970: 90); Good (1987: 69). On the hypostatic Wisdom in early Enochic traditions, especially in chapter 42 of the Book of the Similitudes, see MacRae (1970: 91-2).

48. MacRae (1970: 90).

49. On the imagery of Sophia in Gnostic materials, see Stead (1969: 75-104); MacRae (1970: 86-101); Wilckens and Fohrer (1971: 465-526); Yamauchi (1978: 143-75); Rudolph (1980: 220-37); Sieber (1981: 788-95); Goehring (1981: 16); Gilhus (1985: 95-104); Good (1984: 193-201; 1987); King (2000: 76-7, 96-112, 158-86, 211-27). 
50. On Sophia's connection with the origin of the seven rulers, see Good (1987: 39ff).

51. Layton (1989: 2.37).

52. Layton (1989: 1.235-7): "His thoughts became blind. And, having expelled his power - that is, the blasphemy he had spoken - he pursued it down to chaos and the abyss, his mother, at the instigation of Pistis Sophia (Faith Wisdom). And she established each of his offspring in conformity with its power - after the pattern of the realms that are above, for by starting from the invisible world the visible world was invented. As incorruptibility looked down into the region of the waters, her image appeared in the waters; and the authorities of the darkness became enamored of her."

53. Cf. 2 Enoch 48.1-5 (Andersen 1983: 174): "the sun, so that he might travel along the seven celestial circles, which are appointed with 182 thrones so that he might descend to the shortest day, and once more 182 so that he might descend to the longest day. He also has two great thrones where he pauses when he turns around in this direction and in the other direction, higher than the lunar thrones. From the month Tsivan, from the 17th day, he descends until the month Theved; and from the 17th day of Theved he ascends. And in this way the sun moves along all the celestial circles. When he comes close to the earth, then the earth is merry and makes its fruit grow. But when he goes away, then the earth laments, and the trees and all fruits have no productivity. All this is by measurement, and by the most precise measurement of the hours. He fixed it by measure, by his own wisdom, that is everything visible and invisible."

54. On the Manichaean tradition about the eschatological dissolution of the world and the establishment of the new paradisal aeon outside of the world, see Heuser (1998: 86). Cf. also Kephalaia 29 (Gardner 1995: 32): "entire universe in it today. Yet, at the end, in the dissolution of the universe, this very counsel of life will gather itself in and sculpt its soul in the Last Statue. Its net is its Living Spirit, because with its Spirit it can hunt after the light and the life that is in all things; and build it upon its body."

55. Andersen (1983: 191-3). The longer recension provides the following description that differs in several details from the account found in the shorter recension (Andersen 1983: 190-92): "Listen my children! Before ever anything existed, and before ever any created thing was created, the Lord created the whole of his creation, visible and invisible ... And when the whole creation, visible and invisible, which the Lord has created, shall come to an end, then each person will go to the Lord's great judgment. And then all time will perish, and afterwards there will be neither years nor months nor days nor hours. They will be dissipated, and after that they will not be reckoned. But they will constitute a single age. And all the righteous, who escape from the Lord's great judgment, will be collected together into the great age. And the great age will come about for the righteous, and it will be eternal. And after that there will be among them neither weariness <nor sickness> nor affliction nor worry nor want nor debilitation nor night nor darkness. But they will have a great light, a great indestructible light, and paradise, great and incorruptible. For everything corruptible will pass away, and the incorruptible will come into being, and will be the shelter of the eternal residences."

56. According to the text, "all the righteous, who escape from the Lord's great judgment, will be collected together with [into] the great age."

57. The account describes the cataclysmic collapse of the spatial and temporal order that, according to the text, will lead to a situation when "all time will perish, and afterwards there will be neither years nor months nor days nor hours. They will be dissipated, and after that they will not be reckoned."

58. Andersen (1983: 194).

59. Andersen (1983: 190).

60. For the influence of the Mesopotamian traditions on the Enochic materials, see Zimmern (1903: 530-43); Ludin Jansen (1939); Grelot (1958: 5-26, 181-210); Neugebauer (1985: 387); VanderKam (1984); Kvanvig (1988); Orlov (2005: 23-39). 
61. For detailed analysis of the Mesopotamian sources about seven apkallu, see Kvanvig (1988).

62. See Finkelstein (1963: 50, n. 41); Hallo (1970: 62-3); Hartman (1972: 28, n. 10); Bryan (1987).

63. "They [deities] showed him [Enmeduranki] how to observe oil on water, a mystery of Anu, [Enlil and Ea], they gave him the tablet of the gods, the liver, a secret of heaven and [underworld], they put in his hand the cedar[-rod], beloved of the great gods" (Lambert 1967: 132).

64. Thus, in Midrash Ha-Gadol, Enoch is defined as the "Beloved Seventh."

65. 1 Enoch 1.2.

66. Knibb (1978: 2.100).

67. On this mediatorial office of the seventh antediluvian hero see Orlov (2005: 59-70).

68. In his book about the symbolism of pillars in Jewish mysticism, Idel refers to a passage from the Book of Bahir that depicts the righteous person as the pillar reaching the heaven (Abrams 1994: 160-61): "There is a pillar from earth to heaven, and its name is Tzaddiq, according to the name of righteous men. And when there are righteous men in the world, then the pillar is strengthened, but if not - it becomes weak. And it supports the entire world, as it is written: 'the righteous are the foundation of the world.' But if it is weakened, it cannot support the world. This is the reason why even if there is only one righteous [in the world], he maintains the world." Idel (2005: 80-81) points to the assumption about the dual status of the righteous discernable in the passage from the Book of Bahir: there are righteous humans in the world, but there is also a cosmic righteous and the former depend on the latter. It is noteworthy that Idel traces the origins of this concept of the cosmic righteous to the conceptual developments found in the Slavonic Enoch where "the Great Aeon, which is identical to the foundation, passes for the righteous." In light of this identification Idel proposes that in 2 Enoch the implicit connection might exist between the protological and eschatological foundations, the first represented by the primeval aeon Adoil and the second by the eschatological aeon, which is said to be the final place where all righteous of the world will be gathered.

69. It may be tempting to construe this rabbinic passage as a mere reference to the moral behavior that "sustains" the ethical order of the world. Idel (2005: 75), however, observes that the passage from the Hagigah has not only a moral but also a cosmological significance; he remarks that "the Hagigah, a short but highly influential passage, is a part of mythical cosmology rather than a mode of making sense of religious behavior. To be clear, the basic context of the discussion is cosmology, and its influence on the way in which the righteous should be understood is only an aside."

70. One of the striking features found in the Hagigah's account is a reference to the sevenfold nature of the world's foundation, a tradition also prominent in another passage from the Zohar, which speaks about the seven pillars that sustain the creation. Thus Zohar 1.231a (Tishby 1994: 2.571) reads: "Rabbi Jose began by quoting 'Upon what were its foundations fastened?' (Job 38:6). This verse was spoken by the Holy One, blessed be He, because when he created the world He created it upon pillars, the seven pillars of the world, as it is said 'She has hewn out her seven pillars' (Prov. 9:1), but it is not known what these seven pillars stand upon, for it is a profound mystery, the most recondite of all." It is intriguing that both, Hagigah's account and the Zohar, in their discussion of the foundation theme, mention a tradition about the seven pillars of Sophia from Proverbs 9:1, the tradition that might stand behind the motif of Sophia's creation of humanity from the seven elements.

71. b. Hagigah $12 b$.

72. Thus according to Jubilees 4.23 (VanderKam 1989: 2.28), thanks to Enoch "the flood water did not come on any of the land of Eden because he was placed there as a sign 
and to testify against all people in order to tell all the deeds of history until the day of judgment."

73. Idel (2005: 85).

74. The term "world" (עולם) in the angelic title appears to signify the entire creation. Schäfer (1975: 55) observes that in rabbinic literature the Prince of the World is understood as an angel set over the whole creation. His duties include praying together with the earth for the coming of the Messiah and praising God's creative work.

75. On the role of Enoch as the Governor of the World in 2 Enoch, see Orlov (2005: 159-61).

76. Tantlevskij (2000: 185) observes that in 3 Enoch 8, Enoch-Metatron has qualities by which, according to b. Hagigah 12a and Avot de Rabbi Nathan A 27.43, the world was created and is sustained.

77. Idel (2005: 88).

78. One of such descriptions can be found in Synopse $\$ 12$ (3 Enoch 9: Alexander 1983: 263) which portrays the metamorphosis of Enoch's body into a gigantic extent matching the world in length and breath: "I was enlarged and increased in size till I matched the world in length and breath. He made to grow on me 72 wings, 36 on one side and 36 on the other, and each single wing covered the entire world."

79. It appears also that both Enoch and Adoil are envisioned in the text as the sacerdotal foundations. In our previous discussion about the primordial aeon Adoil, it has been noted that he seems to be identified with the upper sacred foundation that serves as the basis for the heavenly Temple represented by the Throne of God, which is envisioned in the text as the center of the created order. It is intriguing that, similar to Adoil who serves as the upper foundation of the heavenly Temple, Enoch appears to be conceived as the sacerdotal foundation of the earthly Temple. In 2 Enoch, immediately after Enoch's instructions to his sons before his second and final ascension to the highest heaven, the firstborn son of Enoch, Methuselah, and his brothers constructed an altar at Akhuzan, the exact location from which Enoch had been taken up. The place of the hero's departure then becomes envisioned in the text as the sacerdotal center of the earthly realm, where priestly initiations and expiatory sacrifices involving animal blood take place. It is no coincidence, therefore, that 2 Enoch identifies the place Akhuzan as the center of the world. This arcane Slavonic word is traced by scholars to the Hebrew word אחזה, "special property of God," which in Ezekiel 48:20-21 is applied to Jerusalem and the Temple (Milik 1976: 114). Here, similarly to Adoil's protological role connected to the motif of the Throne of the Deity, Enoch's eschatological role is tied to the idea of the earthly counterpart of the Throne, the earthly Temple. The vertical axis of the Throne and the Temple is thus explicitly reaffirmed in the text, as is the horizontal line connecting the protological and eschatological events. Later in the text Akhuzan also receives the additional protological reaffirmation of being identified with the place of Adam's creation. Here the protological and eschatological "pillars" are erected on the same place and the starting point of creation becomes the place where eschatological consummation begins.

80. Andersen (1983: 193). See also 2 Enoch 66.7, the longer recension (Andersen 1983: 194): "How happy are the righteous who shall escape the Lord's great judgment; for they will be made to shine seven times brighter than the sun."

81. Enoch's metamorphosis before the Face is also repeated in 2 Enoch 39. Böttrich (1992: 112-13) previously argued that these two pivotal descriptions of the divine Face in 2 Enoch 22 and 39 represent later interpolations. Yet, in light of recently discovered Coptic fragments of 2 Enoch, that contain a portion of 2 Enoch 39 with a description of the divine Face, Böttrich's hypothesis must now be dismissed as erroneous.

82. Enoch's metamorphosis into a luminous celestial creature presupposes another eschatological trait mentioned in his descriptions of the final aeon of the righteous, namely the state of incorruptibility. In 2 Enoch 65.8-10 (Andersen 1983: 192) Enoch says 
that at the end of times all the righteous who will escape the Lord's great judgment will eventually attain the condition of incorruptibility since they "will be collected together into the great age ... And they will have a great light, a great indestructible light, and paradise, great and incorruptible. For everything corruptible will pass away, and the incorruptible will come into being, and will be the shelter of the eternal residences." The longer recension's emphasis on the incorruptibility of the future condition of the righteous gathered in the final aeon seems again to recall the patriarch's newly acquired celestial state. One of the important features hinting at the patriarch's incorruptible nature is revealed during his brief visit to earth when after his luminous transformation God sent him back to the lower realm to deliver final directions to his children. In 2 Enoch 56, during Enoch's instructions, Methuselah asks his father for a blessing so that he may prepare some food for him to eat. The translated hero, however, politely declines the offer to share earthly food lamenting that nothing earthly is agreeable with his current condition: "Listen, child! Since the time when the Lord anointed me with the ointment of his glory, food has not come into me, and earthly pleasure my soul does not remember; nor do I desire anything earthly" (2 Enoch 56.2, the longer recension: Andersen 1983: 182). In the shorter recension of 2 Enoch, the patriarch's rejection of food is even more decisive: "Listen my child! Since the time when the Lord anointed me with ointment of my glory, it has been horrible for me, and food is not agreeable to me, and I have no desire for earthly food" (Andersen 1983: 183). In this passage an important link is made between the changes in his nature during his luminous metamorphosis near the Throne of Glory and his newly acquired condition of incorruptibility, which portends the future state of the righteous in the final aeon. Here again, through his connection with the eschatological state of incorruptibility Enoch appears to be fashioned as the first fruit of the future aeon of the righteous, or maybe even as the one who already joined this final age. In this respect it is notable that in 2 Enoch 55 Enoch tells his sons before his final departure that he shall go up to the highest heaven into his "eternal inheritance" (Andersen 1983: 182-3).

83. On the Manichaean eschatological "Statue" made from the particles of light rescued by the elect, see Widengren (1965: 68); Heuser (1998: 86-7). Cf. also Kephalaia 54 (Gardner 1995: 58): "Then the summons and the obedience, the great counsel that came to the elements, which are set in conjunction. It mixed with them, it was established in silence. It bears up until the end time when it can arise and stand firm in the great fire. It will gather to it its own soul, and sculpt it in the Last Statue. You will also find it sweeps out and casts from it the pollution that is foreign to it. However, the life and the light that are in all things it gathers in to it, and builds upon its body. The when this Last Statue will be perfect in all its limbs, then it can become free and ascend from that great struggle through the Living Spirit its father, the one who comes and brings a limb. He brings it up from within this gathering, the melting down and destruction of all things." Kephalaia 75 (Gardner 1995: 76): "the Last Statue will be sculpted from the remnant of all things." Kephalaia 81 (Gardner 1995: 83): "At the end also it can gather itself together and sculpt its own self in the Last Statue. And it separates light from darkness." Kephalaia 86 (Gardner 1995: 89): "Also another great and glorious work he will enact at the end is the Last Statue, which he will bring up to the aeons of light." On the concept of the Last Statue as the corporeal gathering of the righteous souls see also Kephalaia 149-50 (Gardner 1995: 157-8): "The fourth time when they weep is when the Statue will be taken up on the last day, and they will weep for the souls of the liars and blasphemers; for they may give ... because their limbs have been severed ... of the darkness. And also those souls, when the Statue will go up and they are left alone, they will weep in that will remain behind in affliction for ever. For they will be cut off and separated from the Last Statue. And it is a necessity to take these souls who are ready for loss as retribution for the deeds that they have done. They go in to this darkness 
and are bound with the darkness; just as they desired it and loved it, and placed their treasure with it. At that very moment, when the Last Statue rises up, they will weep. And they will scream out loud because they will be severed from the company of this great Statue. And they remain behind for ever. This great weeping is terrible, it occurs in front of the souls."

84. Cf. Kephalaia 71 (Gardner 1995: 73): "from when the First Man went down to the contest, till the time when the Statue comes in ... this time ... he appeared ..." Kephalaia 71 "it is the time that occurred from the coming down of the First Man till the going up of the Last Statue."

85. Cf. Kephalaia 104 (Gardner 1995: 107-8): "The first death is from the time when the light fell to the darkness, and was mixed in with the rulers of darkness; until the time when the light will become pure, and be separated from the darkness in that great fire. The reminder left behind there can build and add to the Last Statue."

86. In 2 Enoch 33 (Andersen 1983: 156), the Lord tells the visionary that He himself is responsible for creating everything "from the highest foundation to the lowest, and to the end." The shorter recension (Andersen 1983: 157) also stresses the totality of the creative work of the Deity: "I have contrived it all - I created from the lowest foundation and up to the highest and out to the end." 2 Enoch's emphasis on the Deity's role as the Creator shows a significant parallel to the Jewish mystical imagery in which God is sometimes referred as Yoser Bereshit, "the Creator."

87. Orlov (2005: 191).

88. The access of the seventh antediluvian hero to the cosmological secrets is already manifested in the Enmeduranki tradition where Enmeduranki receives the secret of heaven and underworld. Later rabbinic materials also underline the expertise of Enoch-Metatron in the secrets of creation. On these developments, see Orlov (2005: 31-4).

89. Deutsch (1999: 44-5). See also Bousset (1907: 200); Fossum (1985: 310ff).

90. Variants include the words מטטור מיטטור.

91. Midrash Rabbah, 1.36 .

92. Fossum (1985: 310).

93. Fossum (1985: 301).

94. 2 Enoch 40.2, the shorter recension (Andersen 1983: 165): "I have fully counted the stars, a great multitude innumerable." In Psalm 147:4 God counts the number of all the stars. See also Ezekiel the Tragedian, Exagoge 79-80: "A multitude of stars fell before my knees and I counted them all."

95. Some scholars propose that the name Metatron may be derived from which can be rendered as "keeper of the watch," a noun possibly derived from the root נטר, "to guard, to protect" (Odeberg 1973: 125). Odeberg points to the earliest instance of this derivation in Shimmusha Rabbah, where Enoch was clothed with the splendor of light and made into a guardian of all the souls that ascend from earth.

96. Deutsch (1999: 99). On the eschatological pillar of the souls in the Manichaean and Zoharic traditions, see Idel (2005: 101-33).

97. b. Avodah Zarah 3b (Epstein 1935-52: 3b) depicts Metatron as a teacher of the souls of those who died in their childhood: "What then does God do in the fourth quarter? - He sits and instructs the school children, as it is said, Whom shall one teach knowledge, and whom shall one make to understand the message? Them that are weaned from the milk. Who instructed them theretofore? - If you like, you may say Metatron, or it may be said that God did this as well as other things. And what does He do by night? - If you like you may say, the kind of thing He does by day; or it may be said that He rides a light cherub, and floats in eighteen thousand worlds; for it is said, The chariots of God are myriads, even thousands shinan." 
98. Synopse $\$ 75$ (3 Enoch 48C.12: Alexander (1983: 313); Schäfer et al. (1981: 36-7) attests to a similar tradition: "Metatron sits (יושב מטטרון) for three hours every day in the heaven above, and assembles all the souls of the dead that have died in their mother's wombs, and of the babes that have died at their mothers' breasts, and of the schoolchildren beneath the throne of glory, and sits them down around him in classes, in companies, and in groups, and teaches them Torah, and wisdom, and haggadah, and tradition, and he completes for them their study of the scroll of the Law, as it is written, 'To whom shall one teach knowledge, whom shall one instruct in the tradition? Them that are weaned from the milk, them that are taken from the breasts." A similar tradition also can be found in the Alphabet of R. Akiba. See Wertheimer (1950-53: 2.333-477).

99. Metatron's role as the leader of the souls might also be reflected in an obscure passage from Zohar 2.161b (Tishby 1994: 2.744-5) where one can find a description of the mysterious angelic "officer" put in charge of the souls: "The whole of [hu]mankind, even before they entered this world, were all present in their own stature and shape, just as they are in this world, in a single storehouse, where all the souls in the world are clothed with their forms. And when the time comes for them to be summoned to go down into the world, the Holy One, blessed be He, calls a particular officer whom the Holy One, blessed be He, has put in charge of all the souls that are to go down into the world. And He says to him: Go, and bring me the spirit of so-and-so. At that precise moment that very soul comes, garbed in the form of this world, and the officer presents it to the holy King. The Holy One, blessed be He, then speaks to it and makes it swear that once it has descended into the world it will study the Torah ... And whoever lives in this world and does not study the Torah in order to gain a knowledge of Him - it were better for him not to have been created, for it was for this very reason that the Holy One, blessed be He, brought man into this world." Here similar to the Metatron passages found in b. Avodah Zarah and Sefer Hekhalot one can see again the motif of the importance of the study of the Torah that coincides with the tradition about the angelic captain of the souls. The description found in the Zohar also refers to the imagery of the storehouse of the souls which in its turn brings to memory the motifs found in the Slavonic apocalypse with its imagery of the protological and eschatological reservoirs in the form of the womb of the primordial aeon Adoil and the final aeon where all the righteous souls will be gathered.

100. It is possible that similar to the Manichaean traditions, Metatron can be also understood as the "Last Statue" or the corporeal collection of all righteous souls. Cf. Kephalaia 165 (Gardner 1995: 174): "Again, when the sun sinks from the universe and sets, and all people go in to their hiding places and houses and conceal themselves; this also pertains to the mystery of the end, as it presages the consummation of the universe. For, when all the light will be purified and redeemed in the universe at the last, the collector of all things, the Last Statue, will gather in and sculpt itself. It is the last hour of the day, the time when the Last Statue will go up to the aeon of light."

101. It is intriguing that Numbers Rabbah 12.12 (Freedman and Simon 1961: 5.482-3) depicts Metatron as being in charge of the souls of the righteous whom he offers as the atonement for the sins of Israel: "R. Simon expounded: When the Holy One, blessed be He, told Israel to set up the Tabernacle He intimated to the ministering angels that they also should make a Tabernacle, and when the one below was erected the other was erected on high. The latter was the tabernacle of the youth (משכן הנער) whose name was Metatron, and therein he offers up the souls of the righteous to atone for Israel in the days of their exile." 